\title{
Influenced Factors on Employees' Attitudes toward Organizational Change at Vietnam-Hungary Industrial University
}

\author{
Khuong Thi Thu Hai \\ Viet - Hung Industrial University, Hanoi, Vietnam
}

*Corresponding Author: Khuong Thi Thu Hai, Viet - Hung Industrial University, Hanoi, Vietnam

\begin{abstract}
In the complex and fast changing environment as today, changing management takes more and more important role, especially problem related employees' attitudes toward organization change and their strong influence on effective change of organization in many fields. This study aims to investigate the influence of some factors on employees' attitudes toward organizational change at Vietnam - Hungary Industrial University, (another name, Viet - Hung Industrial University), (abbreviation is VIU); in order to find effective solutions in change management to help the University achieve their targets and mission to 2030. Research results shown that all factors including receptivity to change, readiness to change, commitment to organization, trust in management, communication and training need have statistically significant relation to willingness to support the change. Within, readiness to change, commitment to organization and communication have possitive correlation with employees' attitude towards VIU change; receptivity to change, trust in management and training needs have negative correlation with employees' attitude towards VIU change.
\end{abstract}

Keywords: employees' attitudes; commitment to organization; organization change; receptivity to change; readiness to change.

\section{INTRODUCTION}

Human management always takes an important role in organization in any field, especially in the complex and fast changing environment as today. Many researches suggest that the failure of organizational change initiatives can generally be resulted from negative employee attitudes towards the change, unless adequately managed, organizational change initiatives result in feelings of fear and uncertainty, leading to increased stress, reduced levels of trust between employees and management, and declining levels of organizational commitment (Beer \& Nohria, 2000; Elias, 2009; Anthony Andrew, 2017). In contrast, according to Erich J.Schwarz (2009), employees who have positive attitude towards change in the organization become valuable employees to the organization. To implement change effectively, organization should prepare a clear arrangement and change awareness among employees in order to generate well planned work surroundings and in proportion work agenda to reduce pressure and insecurity.

To join the global education market, universities in Vietnam recently have to take place a lot of big change both in strategy and implementing management. However, many of them faced with the negative attitude of their employees and therefore gain very low effect.

The experimental study was done at Vietnam-Hungary Industrial University (VIU) by a survey with 152 of the VIU's staff on the attitude of employees on VIU changes in 2011-2016 period to investigate the influence of some factors on employees' attitudes toward organizational change at Vietnam Hungary Industrial University (VIU), in order to find effective solutions in change management to help the University achieve their targets and mission to 2030.

\section{LITERATURE REVIEW}

\subsection{Organizational Change}

Organizational change is the movement of an organization away from its present state toward some 
desired future state to increase its effectiveness (Lunenburg, 2010). Change is an unavoidable event arising from the dynamics of environment and it is expected for an organization that desires to grow, achieve its mission, vision and objectives. Organizations have to adapt to the environment to become competitive and stay ahead or at least keep afloat (Rebeka and Indradevi, 2015).

There are different kinds of changes that companies will face during their life time (Mohammad Ali Naghibi and Hediyeh Baban, 2011). Desler (2007) classified four kinds of change basing on aspects of the organization: its strategy, technology, structure and employees (personnel). Rune Todnem By (2007), summaried the literature review and classified change types based on four dimensions: Change Characterised by the Rate of Occurrence; Change characterised by the rate of occurrence; Change Characterised By How It Comes About and Change Characterised by Scale. He also proposed that Change Characterised by How It Comes About was the most common way. When characterised by how change comes about, there are four types of change: Planned change, Emergent change, Contingency change and Choice change.

Change type can be classified by the essential characteristics that describe the kind and form of change; the qualities that make change what it is and many other criteria. Al-Haddad (2014) indicated when the change type is clearly identified, then a manager can choose the most appropriate method to promote change.

\subsection{Employee's Attitude toward Organization Change}

Employee's attitudes towards organizational change may be defined as an employee's overall positive or negative evaluative judgment of a change initiative implemented by their organization (Elias, 2009).

There are two types of employee's attitude towards change: One aspect of employees may have a negative attitude towards organizational change and are more likely to refuse to accept the change; and the other aspect of employees have a positive attitude towards organizational change are more likely to hold up to the change. According to Erich J.Schwarz (2009), employees who have positive attitude towards change in the organization become valuable employees to the organization. Apfelthaler, (2008) revealed employees recognized change with valuable training, which helped in the development of the employees with effective skill.

Sairakhatoon and Ayesha Farooq (2015) shown that employee's attitude is one of the most important determinants of successful organizational change and performance. The more employees are willing, the higher will be the commitment to their organization, and the greater will be the desire to accept organizational change. Employees have positive attitude towards change because change benefits all employees and would enhance work competence and effectiveness.

\subsection{Factors Affecting Employee's Attitude toward Organization Change}

There are many factors that affect employee attitudes towards organisational change have been shown in studies of researchers over the world.

\subsubsection{Receptivity to Organizational Change}

Receptivity to organizational change is shown in many researches as an important factor in successfully implementing organizational change strategies. Becker et al (1996) defined receptivity to change as the willingness of an employee to receive new change ideas in the organization and his/her beliefs in the effectiveness of change programs. Huseyin Durmaz (2007) found that officers more receptive and ready for change have more positive attitudes toward organizational change.

\subsubsection{Readiness for Organizational Change}

Organizaion change success depends on readiness to change of both organization and invidual level. In both level, the high readiness to change will make all members exert greater effort, exhibit greater persistence, and display more cooperative behavior.

Readiness is most often considered in conjunction with methods for reducing resistance to organization change. Coch and French (1948) recommended managers stress the need for changes and thus create readiness during meetings with employees in order to overcome resistance to change. And this point of view is prove by many following researchers (Armenakis et al., 1993; Holt, 2002; 
Huseyin Durmaz, 2007; Weiner, B.J., 2009 ;...). Recently, Anthony Andrew (2017) shown that the correlation between Individual attitude and employee readiness for organizational change at $5 \%$ significance level are strong positive significant relationship $(r=0.595, \operatorname{Pr}<0.000)$.

\subsubsection{Commitment to Organization}

The understanding of organizational commitment began with Becker's early work (1960) showing that people engage in 'consistent lines of activity' and stay with their organization because of the perceived costs they associate with discontinuing the activity, or leaving the organization. Up to now, Allen and Meyer are leading with their research showing that commitment comprises of the psychologically separate states of affective, normative and continuance commitment with subelements of high sacrifice and low alternative influences on continuance commitment.

Many researchers such as Vakola and Nikolaou (2005), Visagie and Steyn (2011), Wageeh A. Nafei (2014), Yousef D. A. (2017) found that organizational commitment has strong correlation with attitudes toward organizational change.

\subsubsection{Trust in Management}

Huseyin Durmaz (2007) defined trust in management as the willingness of an officer to be vulnerable to the actions of competent authorities based on the expectation that they will perform a particular action important to the employee.

Weber, P.S. and Weber, J.E. (2001) Albrecht's (2002) Huseyin Durmaz (2007) Naimatullah Shah (2014) showed that employees trust in management has positive and significant impact on developing positive attitudes and behaviours.

\subsubsection{Communication of Organizational Change}

One major approach to successful implement the organization change is through the establishment of good communication process and information strategies within the organization; as communication is well recognized as influential to organizational growth and survival (Bordia et al., 2004). Huseyin Durmaz (2007) described communication of organizational change as the extent to which an officer receives necessary information about organizational changes in the agency.

Both researches of Stanley et al. (2005), Durmaz (2007) and Elving (2008) shown that communication in organizations have positive correlation with employee's attitude to change.

Recently, Simoes \& Esposito (2014) indicated that communication plays a key role in diminishing uncertainty and ambiguity surrounding the change, and as such impacts on buy-in and successful implementation.

\subsubsection{Training}

Organization changes often cause stress to employees regardless of what their position are in the organization. Lack of information or inaccurate information may produce negative attitudes toward change. In order to avoid such a problem, management is supposed to train personnel regarding the change program beforehand. Explaining the logic of the change prevents groundless rumors in the organization (Kotter \& Schlesinger, 1979).

Research of Vakola \& Nikolaou (2005) also shown the same view that the unknown behind the change programs and the vagueness about what will be happen in the future bothers people and increases the desire to maintain the status quo. Training staff about the change is a way to eliminate such fear and uncertainty and to minimize resistance levels among the staff. In addition, Durmaz (2007) research found that training is a significant predictor of officer attitudes, that also mean officers who believe that they received adequate in-service training hold more positive attitudes toward organizational change.

\subsection{Related Researches in Education}

Education organizations are constantly facing the demands of change to meet the demand for effective human resource training for socio-economic development. That requirements of change lead a lot of change in education organization: change in the physical environment, change in the curriculum, change in faculty and staff, change in the student body, unexpected change, and most importantly 
change that can bring about vast improvements in a school district, community college, or university. The education environment is constantly changing, and the school organization must adapt to these forces in order to remain relevant and effective (Blankstein, 2010). Therefore, as Grant (2003), managing organizational change in higher education is more multifaceted than in other organizations. For organizations to overcome resistance to change, stakeholders at all levels must become involved in the process of change. Even as administrators reach out to resistors, administrators must also stay linked with the "adaptors" (McBride, 2010), those members of the faculty and staff who are committed to new ideas, methods, or devices. It is important to remember that resistant faculty and staff can negatively impact an institution's ability to implement change. Resistance can keep an institution of learning from continued growth whether the resistance is rooted in the contagious effects of cynicism or not.

Fred C. Lunenburg (2010) reviewed the educational organization change literature and listed the most important forces for and resistances to change that confront school organizations and its leaders (as in Figure 1).

Figure1: Forces for and resistance to organizational change

\begin{tabular}{|l|l|}
\hline \multicolumn{1}{|c|}{ Forces for Change } & \multicolumn{1}{c|}{ Resistance to Change } \\
\hline External Forces & Uncertainty \\
\hline Marketplace & Concern over personal loss \\
\hline Government laws and regulations & Group resistance \\
\hline Technology & Dependence \\
\hline Labor markets & Trust in administration \\
\hline Economic changes proposed & Awareness of weaknesses in the change \\
\hline Internal Forces & Administrative processes People problems \\
\hline
\end{tabular}

Source: Fred C. Lunenburg (2010)

Both external and internal forces can create the need for change in educational organizations. These include factors such as the marketplace, government laws and regulations, technology, labor markets, economic changes, administrative processes, and people problems. Organization members often resist change because of the uncertainty it creates, concern over personal loss, group norms, the need for dependence, trust in the leader, and awareness of weaknesses in the proposed change. Force-field analysis can help educational organization leaders understand resistance to change. Educational organization leaders must encourage driving forces for change and reduce resisting forces to change. The change process also passes through three stages: refreezing, moving, and unfreezing. School leaders also can use specific tactics for overcoming resistance to change including education and communication, participation and involvement, facilitation and support, negotiationand agreement, manipulation and co-optation, and explicit and implicit coercion.

\section{CONCEPTUAL FRAMEWORK}

To achieve the research objective, and depend on the literatures that explain above the researcher will use the following conceptual framework.

\section{Independent Variable $\quad$ Dependent Variable}

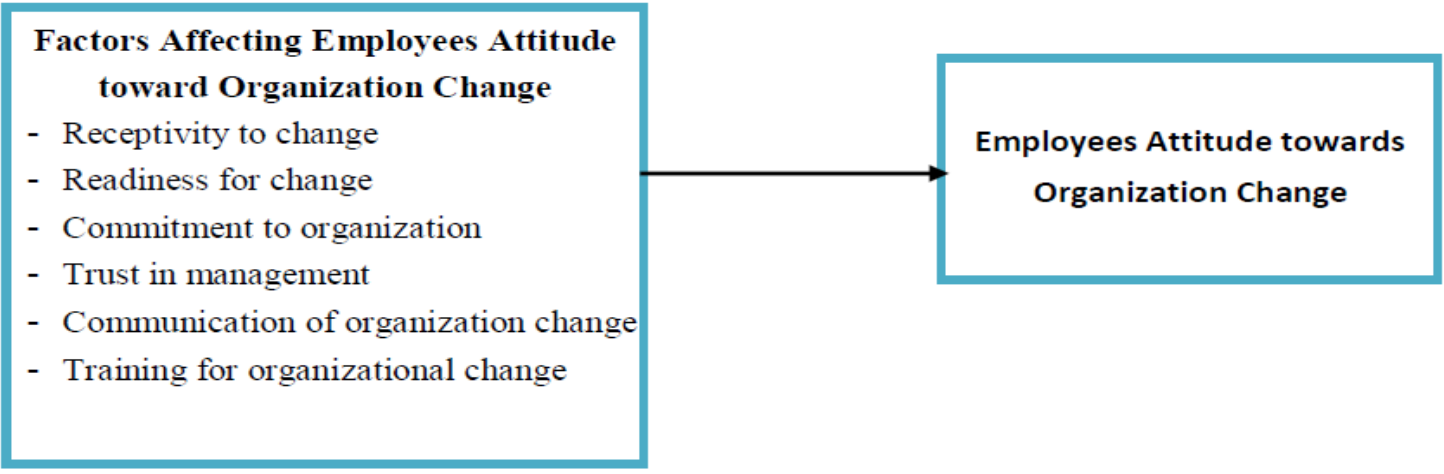

Figure2: Conceptual framework 
Dependent variable of this study is Employee attitude toward VIU changes (using 5 point Likert scale: 1. Strongly disagree 2: Disagree; 3. Neutral; 4. Agree; 5. Strongly agree) are code as scale variables).

Affecting Variable including Receptivity to change; Readiness for change; Commitment to organization; Trust in management; Communication of organization change; Training for organizational (using 5 point Likert scale: 1 . Strongly disagree 2: Disagree; 3. Neutral; 4. Agree; 5. Strongly agree) are code as scale variables and propose to have relationship with Employee attitude toward VIU changes. Regression by SPSS and STATA is use to test this hypothesis and explore the relation between these variables.

\section{HYPOTHESIS}

H1: Receptivity to change has correlation with employee's attitude toward organization change.

$\mathrm{H}$ 2: Readiness for change has correlation with employee's attitude toward organization change.

H3: Commitment to organizational has correlation with employee's attitude toward organization change.

H4: Trust in management has correlation with employee's attitude toward organization change.

H5: Communication of organization change has correlation with employee's attitude toward organization change.

H6: Training for organizational has correlation with employee's attitude toward organization change.

\section{MeTHOdOLOGY}

The population of this survey is 278 employees including managers, lecturers; office staffs in VIU who are working at VIU.

The respondents of this study are employees at VIU.

The sample size: The sample size of population 278 employees according to Slovin fomular (with error $\Delta=0.05$ ) was about 160. 160 questionnairs were delivered to respondent, however, after collection process, only 152 questionnairs gave enough information and were used to analyse.

The sampling procedure that is used is cluster sampling and it is a probability sampling procedure therefore all elements had an equal opportunity of being included in the sample.

Research instrument: A "Survey questionnaire" is a tool for collecting data for research. Survey questionnaires consist of 2 parts: Part 1 is including the profile of the respondents including Age, gender, Position, Education and Experience. Respondent answers the question by chosing a most suitable given selection in questionnaire. Part 2 is assessment of the respondents about influence of factors on Employees attitudes toward organizational change in VIU.

Data gathering procedure: self-made questionnaire

Statistical treatment: The statistical SPSS and STATA software are then used to run the data.

\section{RESUltS AND DiscusSion}

\subsection{The Demographic Profiles of the Employees}

Table1: Profile of respondents

\begin{tabular}{|l|l|l|l|}
\hline & Freq & & Freq \\
\hline Gender & & Education & \\
\hline Female & 64 & Doctor & 12 \\
\hline Male & 88 & Master & 104 \\
\hline Age & & University & 36 \\
\hline $25-35$ years old & 40 & Experience & \\
\hline$>35$ years old & 112 & $1-5$ years & 8 \\
\hline Job position & & $6-10$ years & 44 \\
\hline Lecturer & 80 & $11-15$ year & 72 \\
\hline Vice Rector/higher position & 60 & More than 15 years & 28 \\
\hline Managing staff & 12 & Total & 152 \\
\hline
\end{tabular}


The respondents are classified by various demographic characteristics, including gender, age, job position, highest level of education and working experience or number of working years. Table 1 presents the details on frequency and percentages of each group.

In 152 respondents, the vast majority (58\%) were male, mostly faculty or holding management positions; over $70 \%$ of the age group over 35 and nearly $95 \%$ have been working in VIU for more than 5 years.

\subsection{Employee attitude to VIU change}

Table2: Employees' attitude toward organizational changes in structure

\begin{tabular}{|l|l|l|l|l|l|}
\hline \multirow{2}{*}{ Employees' attitude } & \multicolumn{5}{|l|}{ Employees' attitude toward organizational changes } \\
\cline { 2 - 6 } & Structure & Management & Pesonel & Postion & Repqiurement \\
\hline Strongly agree & $13.16 \%$ & $10.53 \%$ & $13.16 \%$ & $7.90 \%$ & $2.63 \%$ \\
\hline Agree & $42.11 \%$ & $57.89 \%$ & $47.37 \%$ & $44.74 \%$ & $65.79 \%$ \\
\hline Neutral & $42.11 \%$ & $26.32 \%$ & $34.21 \%$ & $39.47 \%$ & $26.32 \%$ \\
\hline Disagree & $2.63 \%$ & $5.26 \%$ & $0.00 \%$ & $2.63 \%$ & $5.26 \%$ \\
\hline Strongly disagree & $0.00 \%$ & $0.00 \%$ & $5.26 \%$ & $5.26 \%$ & $0 \%$ \\
\hline
\end{tabular}

In general, most of employees show their positive attitude towards changes of organization, management, personnel, position and requirements. Only very small percent employees that have negative attitude towards changes. 2.63\% disagree and $42.11 \%$ are neutral to changes of organization; $5.263 \%$ disagree and $26.32 \%$ neutral to changes of management; $5.263 \%$ disagree, $34.21 \%$ neutral to changes in personnel; $5.263 \%$ disagree and $26.32 \%$ neutral to changes in requirement.

\subsection{Impact of Factors on Employee's Attitude toward VIU Change}

Table 3 represents the difference on the factors affecting employees' attitude towards VIU change. As in Table 3, we can see that all factors including receptivity to change, readiness to change, commitment to organization, trust in management, communication and training need have statistically significant relation to willingness to support the change. All factors in model explain $66 \%$ result of changing in employees' attitude towards VIU change.

According to Cohen (1988), readiness to change, commitment to organization, trust in management and communication have average correlation with employees' attitude towards VIU change; receptivity to change and training needs have weak correlation with employees' attitude towards VIU change. Readiness to change, commitment to organization and communication have possitive correlation with employees' attitude towards VIU change; receptivity to change, trust in management and training needs have negative correlation with employees' attitude towards VIU change.

Table3: Difference on the factors affecting employees' attitude towards organizational change

\begin{tabular}{|l|l|}
\hline \multicolumn{2}{|c|}{ Employees' attitude towards organizational change } \\
\hline \multirow{2}{*}{ Receptivity to change } & -0.220 \\
\cline { 2 - 2 } & $(2.75)^{* * *}$ \\
\hline \multirow{2}{*}{ Readiness to change } & 0.459 \\
\hline \multirow{2}{*}{ Commitment to organization } & $(6.61)^{* * *}$ \\
\cline { 2 - 2 } & 0.482 \\
\hline \multirow{2}{*}{ Trust in management } & $(9.00)^{* * *}$ \\
\cline { 2 - 2 } & -0.392 \\
\hline \multirow{2}{*}{ Communication } & $(6.16)^{* * *}$ \\
\cline { 2 - 2 } & 0.398 \\
\hline \multirow{2}{*}{ Training needs } & $(3.82)^{* * *}$ \\
\hline \multirow{2}{*}{ _cons $^{2}$} & -0.253 \\
\cline { 2 - 2 } & $(2.69)^{* * *}$ \\
\hline$R^{2}$ & 1.355 \\
\hline$N$ & $(3.37)^{* * *}$ \\
\hline
\end{tabular}

$* p<0.1 ; * * p<0.05 ; * * * p<0.01$ 
In detail, staffs with high readiness to change, commitment to organization, trust in management and good information flow demonstrate a high probability to support organization for the expected changes. Amongst these variables, readiness to change reveals highest impact, indicating that employees who are ready to change is about $55.5 \%$ more likely to be willing to support the change. It is followed by communication factor. It indicates that employee who supposes to be provided sufficient information is around $40 \%$ more likely to support the change. Likewise, commitment to organization and trust in management also show statistically significant effects on employees' attitude. So

H1: Receptivity to change has correlation with employee's attitude toward organization change, is suported.

H2: Readiness for change has correlation with employee's attitude toward organization change, is suported.

H3: Commitment to organizational has correlation with employee's attitude toward organization change, is suported.

H4: Trust in management has correlation with employee's attitude toward organization change, is suported.

H5: Communication of organization change has correlation with employee's attitude toward organization change, is suported.

H6: Training for organizational has correlation with employee's attitude toward organization change, is suported.

\section{CONClussion}

In overall, commitment to organization and readiness to change serve as the first steps to affect attitudes. Furthermore, other factors, namely, communication and trust in management are also vital element to decide the employees' attitude toward organizational changes.

So that managers of VIU need concern on these following problem when making the university operation plan for change and implementing change:

- Informing employees about the nature of change and the reasons for making change through meetings, presentations, individual discussions, etc...

- Enctheaging participation and employee's involvement in designing as well as implementation stages of the change effort.

- Managers should provide employees with the needed resources to make change. In addition, listening to employee's problems and difficulties is also important.

- Offering employees incentives, to ensure their support and cooperation in change effort.

\section{REFERENCES}

[1] Beer, M., \& Nohria, N. (2000). Cracking the code of change. Harvard Business Review, 78, 133-141.

[2] Elias, S. (2009). "Employee commitment in times of change: Assessing the importance of attitudes toward organizational change." Journal of Management, 35(1), 37-55.

[3] Anthony Andrew (2017). Influence of Employee Attitude on Employee Readiness for Organizational Change. Asian Journal of Economics, Business and Accounting, 5(1): 1-11, 2017; Article no.AJEBA.37126

[4] Erich J. Schwarz, (2009). The effects of attitudes and perceived environment conditions on students, Entrepreneurial intent, vol. 51, pp. 272-291.

[5] Lunenburg. Fred C, (2010), Forces for and resistance to organizational change, National Forum of educational administration and supervision Journal, Vol. 27, Issue 4.

[6] Rebeka, E. and R. Indradevi (2015). A study on perception of employees during change in an organization, Mediterranean Journal of Social Sciences, Vol. 6, No. 1, pp. 72-79.

[7] Mohammad Ali Naghibi and Hediyeh Baban, (2011), Strategic change management: The challenges faced by organizations, 2011 International Conference on Economics and Finance Research IPEDR vol.4, 
IACSIT Press, Singapore, p.542-544.

[8] Desler, G. (2007), Management Principle and Practices for tomorrow's Leaders, 3rd ed, United States of America: Haughton Mifflin.

[9] Rune Todnem By (2007), Organisational change management: A critical review, Journal of Change Management, 5:4, pp. 369-380. Doi: 10.1080/14697010500359250.

[10] Al-Haddad, Serina (2014). Successful Organizational Change: Aligning Change Type With Methods, Electronic Theses and Dissertations.

[11] Apfelthaler, G. et al., (2008). Global entrepreneurship monitor Austria 2007, FH. Joanneum and university of Graz, Graz.

[12] S. Khatoon, A. Farooq (2015), Employees' Attitude toward Change and Organizational Performance, Research and Sustainable Business, Indian Institute of Technology Roorkee, pp.347-353.

[13] Becker, T., Billings, R., Eveleth, D., \& Gilbert, N. (1996). Foci and bases of employee commitment: Implications for job performance. Academy of Management Journal, 39, 464-482.

[14] Huseyin Durmaz, (2007). Officer attitudes toward organizational change in the Turkish national police. Unpublished doctoral thesis, University of North Texas. Texas.

[15] Coch, L., \& French, J. R. P. (1948). Overcoming resistanceto change. Human Relations, 1,512-532.

[16] Armenakis, A. A., Harris, S. G., \& Mossholder, K. W. (1993). Creating readiness for organizational change. Human Relations, 46,681-702.

[17] Weiner, B.J. (2009).\&nbsp; A theory of organizational readiness for change. Implementation Science, 4, 67. doi:10.1186/1748-5908-4-67.

[18] Meyer, J., \& Allen, N. (1997). Commitment in the workplace: Theory, research, and application. Thousand Oaks, CA: Sage.

[19] Vakola, M., \& Nikolaou, I. (2005). Attitudes towards organizational change: What is the role of employees' stress and commitment? Employee Relations, Vol.27 Issue 2, p.160-174. https://doi.org/10. $1108 / 01425450510572685$

[20] Visagie, C. M., \& Steyn, C. (2011), Organisational commitment and responses to planned organisational change: An exploratory study, Southern African Business Review, 15, 98-121.

[21] Wageeh A. Nafei (2014), Assessing Employee Attitudes towards Organizational Commitment and Change: The Case of King Faisal Hospital in Al-Taif Governorate, Kingdom of Saudi Arabia, Journal of Management and Sustainability 4 (1), 1-16. Doi:10.5539/jms.v4n1p204.

[22] Yousef D. A. (2017), Organizational Commitment, Job Satisfaction and Attitudes toward Organizational Change: A Study in the Local Government, International Journal of Public Administration, Vol. 40:1, pp.77-88, Doi: 10.1080/01900692.2015.1072217

[23] Weber, P. S., \& Weber, J. E. (2001). Changes in employee perceptions during organizational change, Leadership \& Organization Development Journal, 22, 291-300.

[24] Albrecht, S. L. (2002). Perceptions of integrity, competence and trust in senior management as determinants of cynicism toward change. Public Administration \& Management: An Interactive Journal, 7. 320-343.

[25] Shah, N., Irani, Z. and Sharif, A.M. (2016), Big data in an HR context: exploring organizational changereadiness, employee attitudes and behaviors, Journal of Business Research, Vol. 70, January, pp. 366-78.

[26] Bordia, P., Hobman, E., Jones, E., Gallois, C., \& Callan, V. J. (2004). Uncertainty duing organizational change: Types, consequences, and management strategies. Journal of Business and Psychology, 18(4), 507-532.

[27] Stanley, D. J., Meyer, J. P., \& Topolnytsky, L. (2005). Employee cynicism and resistance to organizational change. Journal of Business and Psychology, 19,429-459.

[28] Elving, W., \& Hansma, L. (2008). Leading organizational change: On the role of top management and supervisors in communicating organizational change. Paper presented at the Annual meeting of the International Communication Association, Montreal, Quebec, May, 1-45.

[29] Paula Matos Marques Simoes Mark Esposito (2014), "Improving change management: how communication nature influences resistance to change", Journal of Management Development, Vol. 33 Iss 4 pp. 324 - 341. http://dx.doi.org/10.1108/JMD-05-2012-0058

[30] Kotter, J., \& Schlesinger, L. (1979). Choosing strategies for change. Harvard Business Review, 57(2), 106114.

[31] Grant, K. (2003). Making sense of education change at Thistle College: The existence of witchcraft, 
witches and shamans. International Journal of Educational Management, 17(2), 71-83.

[32] McBride, K. (2010). Leadership in higher education: Handling faculty resistance to technology through strategic planning [Electronic version]. Academic Leadership, 8(4), 39.

[33] Lunenburg. Fred C, (2010), Forces for and resistance to organizational change, National Forum of educational administration and supervision Journal, Vol. 27, Issue 4.

[34] Cohen, J., (1988), Statistical Power Analysis for the Behavioral Sciences, second ed, Lawrence Erlbaum Associ-ates, Hillsdale, NJ.

\section{AUTHOR'S BIOGRAPHY}

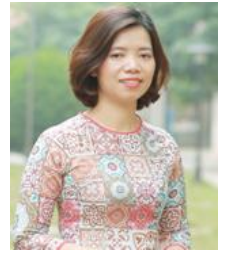

Khuong Thi Thu Hai, DBA is a manager of Viet - Hung Industrial University. She has a thorough knowledge of management. She is also the author of "Impact of SocioDemographic Characteristic on Employees' Attitudestoward Organizational Change at Vietnam - Hungary Industrial University".

Citation: Khuong Thi Thu Hai. “Influenced Factors on Employees' Attitudes toward Organizational Change at Vietnam-Hungary Industrial University" International Journal of Managerial Studies and Research (IJMSR), vol 7, no. 5, 2019, pp. 7-15. doi: http://dx.doi.org/10.20431/2349-0349.0705002.

Copyright: (c) 2019 Authors. This is an open-access article distributed under the terms of the Creative Commons Attribution License, which permits unrestricted use, distribution, and reproduction in any medium, provided the original author and source are credited. 